\title{
Engagement of Occupational Safety and Health at Mahkamah's Welding Worker Medan
}

\section{Eka Lestari Mahyuni*, Kalsum, Muhammad Makmur Sinaga}

Department of Occupational Safety and Health, Faculty of Public Health,Universitas Sumatera Utara

\begin{abstract}
Welding worker was not the easy task because it has a very high physical risk and the process requires special skills and equipment to prevent accident exposed. This devotional activity is carried out in the welding industry at Jl. Mahkamah with two partners, namely CV. M. Nauli and CV. Cahaya. The aim of training activity made the worker able to analyze the hazards in the workplace so that it will be more careful in their work. The result show that the training could develop the worker to be aware about safety and health work patterns. In order to support the work in accordance with occupational safety and health standards, workers are also given pocket books that contain safety and health working methods and also given the self-protection of welding like welding clothes, welding gloves, welding mask, welding glasses and masks. Based on the evaluation of activities, it show that the worker has develop and always using the self protector in their work evenly. It build the good collaboration between them and they are could arrage the rest time with ergonomics relaxation in 5-10 minutes. The workshop station looks better than before and the workshop doing good house keeping before and after their work.
\end{abstract}

Keyword: Welding Worker, Welding Workshop, Occupational Safety, Occupational Health

Abstrak. Pengelasan bukanlah suatu pekejaan yang mudah karena memiliki resiko fisik yang sangat tinggi sehingga dalam pengerjaannya memerlukan keahlian serta peralatan khusus agar seorang pengelas (welder) tidak terkena kecelakaan kerja. Kegiatan pengabdian ini dilakukan di usaha las Jl. Mahkamah Medan dengan mengangat dua mitra yaitu CV. M. Nauli dan CV. Cahaya. Dalam kegiatan ini pekerja yang belum memperhatikan dan mengetahui tentang pola kerja yang aman dan sehat selama melakukan pengelasan diberi sosialisasi awal tentang Keselamatan dan Kesehatan Kerja. Berikutnya kegiatan pelatihan diberikan pada pekerja las dengan tujuan pekerja mampu menganalisis bahaya di tempat kerjanya sehingga akan lebih berhati-hati dalam bekerja. Awareness tentang pola kerja yang aman dan sehat merupakan langkah awal usaha pengelasan dalam membentuk pola kerja yang aman dan sehat. Untuk mendukung cara kerja yang sesuai standar keselamatan dan kesehatan kerja, pekerja juga diberi buku saku 
yang memuat metode kerja yang aman dan sehat. Pekerja juga diberi pelindung diri berupa kaca mata dan masker. Pada usaha mitra tetap diberi pelindung diri yang lengkap meliputi baju las, sarung tangan las, topeng las, kacamata las dan masker. Berdasarkan kegiatan pengabdian ini pekerja las di Jl. Mahkamah mengetahui bahaya yang ada di tempat kerjanya dan menggunakan pelindung diri selama bekerja untuk menghindari dan mengurangi paparan langsung dari sumber kontaminan yang ada selama proses pengelasan.

\section{Kata kunci: Bengkel Las, Kesehatan Kerja, Keselamatan Kerja, Pekerja Las}

Received 26 October 2017 | Revised 23 December 2017 | Accepted 16 March 2018

\section{Introduction}

All occupation either in the company or small workshops, need to attention of safety and health aspect. It's according with the regulation of that requiresafety and health.Regulation No. 1 of 1970, Regulation no. 14 of 1969 clauses 9 and 10, and PERMENAKER No: PER. 02 / MEN 1982 are some of the regulations that regulate the safety and health of welding workers.

The welding is not an easy task as the high risk because in the process requires special skills and equipment, that not given the welder to exposed on work accidents or occupational health diseases. Welding is defined as one of the metal grafting technique by liquefying some parent metal and filler metal with or without pressure and with or without additional metal and producing continuous connection [1].

The hazards and risks that exist in the welding work process are the visible light and ultraviolet rays that affecting the welder's eye. On the other hand, noise exposure in grinding and welding process as well as dark working environment provide a large health impact through welding workers. As an informal sector, it is not uncommon for welding efforts to point out the technical hazards such as unergonomic posture that risk for low back pain or spinal abnormalities.

One of the central welding workshop in Medan City is located at JalanMahkamah Medan with 22 welding workshops and 93 workers. Welding workshop produces a fence yard, gate, door distance, or window of the house, various types of children's games made of iron and others. Welding workshops on JalanMahkamah employ 2 to 8 welding employees associated with the use of welding tools that produce high temperatures and noise. In the process of working a welding unit requires electricity for its operations using several facilities that consist of welding machines, welding cables, clamps or clamps, and other supporting equipment. In addition, the manufacturing process of the products, welding using heat-related machines derived from welding machines, radiation due to welding poses, electricity as a source of machinery, sparks and metal crusts at the time of cutting various metals. 
It is necessary to consider the health and safety of welding workers in order to reduce the occurrence of occupational accidents and diseases that can reduce productivity and reduce the number of working days lost.

\section{Method}

The method of devotion done in any stages are as follows:

a) Persuasive approach in the form of delivery of health messages focused on aspects of occupational safety and health through counseling and socialization.

b) Increased the knowledge for welding workers with training to recognize the hazard of welding work and its impact on health, especially eye health.

c) Demonstrate the use of Standard Welding Face / mask as a hazard reducer due to the welding process.

d) Design and manufacture of pocket book as output and binding rules for welding workers in cooperation with the owner of welding workshop at Jalan Mahkamah Medan.

\section{Results and Discussion}

Occupational Safety and Health is the primary means of to prevent the occupational accidents, disabilities and deaths as the consequences of occupational accidents from potential hazards. Working accidents in addition to causing direct losses also cause indirect losses ie losses on damage to machinery and equipment work, cessation of production processes, environmental damage and others [2].

Welding workshop which is a partner of this dedication are UD M.Nauli and UD Cahaya which is located at Jalan Mahkamah Medan Kelurahan Mesjid Kecamatan Medan Kota. The efforts of these two partners and other welding workshops coexist and the welding workshop is filled with products such as swings, tents, canopy and all products that require the welding process in connection with other ferrous metals.

Based on the socialization activities conducted, the work process in each welding workshop on Jl. Mahkamah has a homogeneous risk. The risk of welding hazardous experienced by welding workers on Jl. Mahkamah includes direct welded light exposure because workers do not use appropriate self-protector, noisy, ergonomic work posture, smoke and paint odor. Workers are never avoided from direct exposure to welding rays and byproducts of welding smoke, Nitrogen Oxide (NOx), Nitrogen Dioxide $\left(\mathrm{NO}_{2}\right)$, infrared rays and ultraviolet light. For a long time with continuous direct exposure, this risk can lead to photoelectric conjunctivitis, as Wahyuniobserved [3], suggesting that prolonged exposure is a risk factor for conjunctivitis 
where workers with a prolonged exposure more than 4 hours/day have a risk of 2.667 more great for conjunctivitis compared with workers with a prolonged exposure $\leq 4$ hours/day. Therefore, one of the safeguards against workers of occupational accident and work health disease that have to be done by the owner of welding workshop is the application and use of eye protection tool by the workers while they work [4].

To support the improvement of safe and healthy working pattern, this dedication to provide Occupational Safety and Health training on welding workerat Jl. Mahkamah. The training was held on 10 August 2017 from 09.00 wib untill finish. The training participants are all the welding workshop workers in Jl. Mahkamah who are willing to participate in the activities of approximately 30 workers and the two partners who work together in community service activities.

Training is provided with lecturing and discussion methods. Training is also accompanied by practice and demonstration of appropriate self-protection for welding workers. In the training provided the team of devotion gives a direct example of the things that are important and are the events experienced by workers. As a result welding workers on J1 Mahkamah acknowledge that complaints on the eyes, chest tightness, changing posture, dizziness and noise and fatigue that is felt to be a fairly interesting discussion.

To avoid this danger is delivered to workers can do the work process by using a personal protector, especially on the eyes to avoid exposure to visible light and ultraviolet light is quite sharp and able to damage the eye organs. The effect of infrared ray on the eye is equal to the influence of heat, swelling of the eyelid, the occurrence of corneal disease, too early presbyopia and aging [5]. Pratiwi et al.in his research at Jember welding workshop found that, overall welding workers have experienced eye health problems after welding process due to not discipline using PPE when working [6].

The dominant work done in this welding is grinding, welding and painting. Of the three processes that workers also do the job with a posture that is not ergonomic. Static position is characterized by an old muscle contraction that usually corresponds to posture and is not recommended to continue static muscle work over the long term as pain arises and forces the workforce to stop. It is also caused by the inappropriate posture such as welding in a squatting position, bending and welding over head and the existence of manual handling activities when moving raw materials. Research shows workers who experience MSDs complaints when a person's work period gets longer causes stress on the muscles of the body due to monotonous work. When the person is required to perform tasks that require exertion, gets tired because the oxygen content in the blood is low and eventually the cigarette effect will create a pain response or as the beginning of pain (osteoporosis, bone undegeneration) resulting from impaired calcium absorption [7]. 
To support the discussion activities that developed during the training, welding workers were also given an intervention by socializing ergonomic gymnastics to reduce the body pain experienced during work. Theseergonomics relaxation are useful stretching movement to reduce fatigue in the body due to static position. Physical exercise in the form of gymnastics will give a positive effect on muscle strength and function and can reduce the pain sensation in the joints [8]. According to Anderson, stretching done regularly can help avoid muscle tension and stiffness [9].

In general, in welding work recommended that workers use Personal Protective Equipment (PPE). The purpose of using PPE is to protect the body from work hazards that may cause work-related accidents and occupational diseases. It is very useful, not only for worker but also for the company [10].

To protect welding hazards should workers use welding mask. The welding mask is used to protect the face from welding rays (ultraviolet light, infrared), weld heat radiation as well as spark weld sparks. if the advance welder is not protected then the skin will burn and skin and skin will be damaged. Face protectors are used to protect the entire face against skin fires resulting from arc light, sparks and other that couldn't be protected by wearing only eye protection. The shape of a variety of face shields can be helmet-shaped and can be a protective barrier [11].

The evaluation result of this activity was done in October 2017 and showed significant change of every welder worker in Jl.Mahkamah. Changes and developments of welding workers is indicated by layout of welding workshops that have been neat, the use of self-protector such as glasses, mask welding and mask in regularly, even workers do relaxation during work when feeling pain in the body due to lift and posture static work. The pocket book and personal protector that has been given has been read and applied in the work process. In overall dedication activities could giving a positive contribution in creating a safety and health welding work pattern on J1. Mahkamah Medan.

\section{Conclusion}

Based on the activities of dedication performed then it can be concluded that welding work process has considerable risk to the safety and health of welding workers, among others: fall, burn, eye irritation, deafness, hand cut, and explosion due to welding tools, cataracts, back pain, burns, fatigue and siderosis. Working safety and health development efforts undertaken can improve the knowledge of welding workers and change work patterns to be safer and healthier to avoid exposure of hazards that impact on welding workers. 


\section{References}

[1] Sonawan, Hery and Rochim Suratman. 2003. Pengantar untuk Memahami Proses Pengelasan Logam, Penerbit Alfabeta, Bandung.

[2] Ningsih, R., A. R., and M. P.A. Paripurno. 2016. Manajemen Risiko Keselamatan dan Kesehatan Kerja (K3) dalam Praktikum Pengelasan (Studi Kasus: di Welding Centre Politeknik Perkapalan Negeri Surabaya). Seminar Nasional Maritim, Sains, dan Teknologi Terapan 2016 Vol. 01 Politeknik Perkapalan Negeri Surabaya, 21 November 2016. Accesssed on pada tanggal 24 Oktober 2017.

[4] Salawati, L. 2015. Analisis Penggunaan Alat Pelindung Mata Pada Pekerja Las Kecamatan Syiah Kuala Banda Aceh. Jurnal Kedokteran Syiah Kuala 15 (3). Accessed on 18 Oktober 2017.

[5] Nurdin, A. 1999. Peralatan Las Busur Manual. Bandung: Angkasa.

[6] Pratiwi, Y.S., Widada, W., and Yulis A.Z.E. 2015. Gangguan Kesehatan Mata Pada Pekerja Di Bengkel Las Listrik Desa Sempolan, Kecamatan Silo, Kabupaten Jember. The Indonesian Journal Of Health Science, Vol. 5, No. 2, Juni 2015. Diakses pada tanggal 20 Juli 2017.

[7] Shofwati, I. 2010. Faktor-faktor yang berhubungan dengan keluhan Musculosceletal Disorders pada Welder di Bagian Fabrikasi PT. Caterpillar Indonesia Tahun 2010. Universitas Islam Negeri Syarif Hidayatullah Jakarta.

[8] Bennel, Ahamed, Bryant, Jull, Hunt, and Kenardy. 2012. A Physiotherapist Delivered Integrated Exercise and Coping Skills Training Intervention For Individuals With Knee Osteoarthritis: A Randomized Controlled Trial Protocol. BMC Musculoskeletal Disorders. Accessed on 24 October 2017 dari http://www.biomedcentral.com

[9] Anderson, B. 2010, Stretching in The Office. Serambi Ilmu Semesta, Jakarta

[10] Budiono, A.M.S. 2003, Bunga Rampai Hiperkes dan Keselamatan Kerja. Badan Penerbit UNDIP, Semarang.

[11] Siswanto, A. 2003. Manajemen Tenaga Kerja Indonesia. Jakarta: PT. Bumi Aksara. 